\title{
A REVIEW OF THE DIRECT AND INDIRECT EFFECTS OF NITROGEN ON BOTRYTIS BUNCH ROT IN WINE GRAPES
}

\author{
D.C. MUNDY \\ The Horticulture \& Food Research Institute of New Zealand Limited, \\ Marlborough Wine Research Centre, P.O. Box 845, Blenheim, New Zealand \\ Corresponding author: dmundy@hortresearch.co.nz
}

\begin{abstract}
Nitrogen is an important macro-nutrient for grapevines, influencing a number of metabolic pathways and plant structures. This review provides a summary of some direct and indirect effects of nitrogen fertilisation on bunch rot incidence in the field. Direct changes due to increased nitrogen nutrition include greater thickness of the wax on berry surfaces and increased concentrations of the biochemical defence compounds produced in them. Indirect changes that result from increased nitrogen include development of tighter bunches and denser canopies. As integrated management systems become more complex, a better understanding of different components such as nitrogen nutrition is required, to allow vineyard managers to make informed decisions on how potential changes to current practices may influence disease and berry quality parameters.
\end{abstract}

Keywords: grape, botrytis bunch rot, integrated management, nitrogen, disease.

\section{INTRODUCTION}

For wine grapes, berries need sufficient nitrogen $(\mathrm{N})$ content to support yeast growth during fermentation (Spayd et al. 1995). To increase the berry nitrogen content grape growers can add $\mathrm{N}$ to the soil as fertiliser (Goldspink \& Frayne 1996) or in other forms such as mulch (Agnew et al. 2002). However, $\mathbf{N}$ additions to vines also influence the growth of tissues and organs other than the berries. Investigations into the influence of $\mathrm{N}$ amendments on grape diseases have often been limited (Huber \& Thompson 2007) and the results conflicting (Elmer \& Michailides 2004). This review focuses on the role of $\mathrm{N}$ in development of botrytis bunch rot (caused by Botrytis cinerea), which is the main disease of grape berries post-véraison in New Zealand (Smart \& Robinson 1991).

The observed level of botrytis bunch rot within a vine may be influenced by the interaction of a number of factors. These include, but are not limited to, the thickness of the wax layer on berries (Rogiers et al. 2005), canopy density, levels of bunch trash (Agnew et al. 2004), inoculum levels (Mundy \& Agnew 2002), berry sugar concentration, physical damage (Hill et al. 1981; Mundy \& Beresford 2007) and $\mathrm{N}$ additions to the vine (Christensen et al. 1994; Keller et al. 2001). Nitrogen nutrition was selected by New Zealand Winegrowers as one factor to review before they should commission new botrytis bunch rot investigations.

\section{VULNERABILITY OF GRAPE BERRIES TO BOTRYTIS BUNCH ROT}

Botrytis cinerea can infect the berries of all grape cultivars but susceptibility varies due their inherent berry defence mechanisms, such as skin and cuticle thickness and metabolic pathways. In addition, vine morphology, especially bunch architecture and vegetative growth of the vine can affect bunch microclimate and, in turn, B. cinerea infection. Bunch and canopy microclimate may be modified to become less conducive to infection by some viticulture practices, such as leaf plucking (Gubler et al. 1987), trellis system 
(Smart \& Robinson 1991) or irrigation methods. Environmental factors such as rainfall, wind, humidity and UV light (Holz et al. 2004) are also important for the initiation of the infection cycle in susceptible fruit. In addition, some vineyard management practices, such as frequency and choice of agrichemical applications, sanitation and understorey management, also affect pathogen survival and disease risk.

\section{B. CINEREA INTERACTION WITH INHERENT BERRY DEFENCES}

Berry defence mechanisms that successfully prevent infection by potential pathogens are governed by genes that provide physical and chemical barriers to infection. In the case of $B$. cinerea infecting a grape berry, the activation of defence genes begins with its attempts to penetrate the cuticle through the development of an appressorium (van Kan 2006), which is mediated by the mpg 1 gene (Snoeijers et al. 2000). However, thickness of a berry cuticle, an inherited feature, can result in resistance to penetration (Commenil et al. 1997; Elmer \& Michailides 2004). Nitrogen nutrition (Keller et al.2001) and management practices such as spraying agrichemicals (Rogiers et al. 2003) also influence the density of the cuticle. Fruit susceptibility also changes over time. From véraison, when berry sugar concentration starts to increase, there is also increasing susceptibility to infection by $B$. cinerea (Mundy \& Beresford 2007). Increased susceptibility with ripening may be related to decreases in skin thickness during ripening (Keller et al. 1998) or cuticle cracking (Commenil et al. 1997).

Following penetration of the cuticle, $B$. cinerea has multiple metabolic pathways that facilitate host cell death (van Kan 2006). One method is by induction of an oxidative burst, which results in a hypersensitive response. Such responses can confer resistance to biotropic pathogens like powdery mildew but can be beneficial to necrotrophs like B. cinerea (van Kan 2006) since they provide nutrient sources for growth. Cells killed by an oxidative burst have low nutrient content, resulting in the induction of this pathogen's vir and path genes and the up-regulation of its metabolic pathways and growth (Snoeijers et al. 2000).

\section{DIRECT INFLUENCE OF NITROGEN}

Nitrogen nutrition affects cuticle development and the biochemical defence compounds produced in the berry, which directly contribute to the ability of $B$. cinerea to cause successful infections. Commenil et al. (1997) reported on the physiological and morphological features of grape berry cuticle development and how they affect development of bunch rot disease. In particular, they investigated the changes in cuticle thickness during berry maturation for three clones of Pinot noir, with different susceptibilities to botrytis bunch rot. They reported that the only physiological or morphological modification of the cuticle in the clone that was most susceptible to bunch rot was a higher level of cuticle cracking. Keller et al. (1998) reported that when high $\mathrm{N}$ was applied as $\mathrm{NH}_{4} \mathrm{NO}_{3}$ at bloom, the weight of skins and the skin to pulp ratio were decreased. Hence the addition of $\mathrm{N}$ to vines had an effect on skin and cuticle development, at least for the cultivar studied. Studies of skin physiology and $B$. cinerea infection processes would be required to investigate how these changes may influence berry susceptibility to infection.

The grape berry still has a number of chemical defence pathways, which can act after $B$. cinerea penetration of the berry skin. Many of the mechanisms rely on amino acids as precursors, and so increases in berry amino acid concentration could influence their production. Keller \& Hrazdina (1998) showed that vine $\mathrm{N}$ had a direct influence on which individual pigments (phenolics) formed in the skin, and Keller et al. (2000) also reported differences in berry chemistry as a result of the light environment. They noted that in green berries, stilbenes (phenolic phytoalexin compounds) stopped or delayed the progress of invasion by $B$. cinerea, possibly because the skins of berries grown in full light accumulated more of these phenols than did the skins of shaded berries. They postulated that the underlying mechanism was through the photosynthetically active leaves being able to produce energy and precursors for stilbene production. Although the observations from these papers suggested that $\mathrm{N}$ addition may increase phenolic production and 
hence reduce the chances of infection, they may also indirectly increase the chance of shading through enhanced shoot growth, thereby reducing stilbene production. However, detailed experiments investigating the interaction between berry phenolic concentration, $\mathrm{N}$ fertilisation and $B$. cinerea infection have not been conducted.

Whole berry bioassays were conducted by Mundy \& Beresford (2007) to investigate the effect of berry $\mathrm{N}$ and sugar concentrations on susceptibility to $B$. cinerea. However, no causal relationship was found between berry $\mathrm{N}$ and incidence of disease.

\section{INDIRECT INFLUENCE OF NITROGEN}

Many tissues within the plant require $\mathrm{N}$. Therefore the addition of $\mathrm{N}$ to the soil does not always result in direct changes to the $\mathrm{N}$ content of the fruit. Researchers have reported a range of nitrogen-grapevine interactions that can indirectly influence the susceptibility of berries to B. cinerea. However, the initial N status of the vines is important, as this will determine how a vine responds to $\mathrm{N}$ fertiliser additions. In a review of physiological responses to $\mathrm{N}$ by grapevines, the apparently contradictory literature was divided into three groups, vines with initially low, medium or high N status (Bell \& Henschke 2005). Within each group, vine responses to $\mathrm{N}$ fertiliser were consistent. Vines with medium levels of $\mathrm{N}$ did not benefit from more $\mathrm{N}$ but still had negative effects such as increased shading. Vines with high $\mathrm{N}$ to start with had all the negative effects of $\mathrm{N}$ addition as well as the possibility of unwanted $\mathrm{N}$ compounds forming in the wine.

The addition of $\mathrm{N}$ fertiliser to vines with low $\mathrm{N}$ levels can have multiple effects, which can increase or decrease the risk of botrytis bunch rot expression in the field. The main reported effects of increased $\mathrm{N}$ fertiliser were increased leaf area and chlorophyll formation, leading to increased production of photosynthates and total yield, but also increased capacity of storage organs and root growth (Bell \& Henschke 2005). Increased leaf area is usually associated with increased canopy density, which may indirectly result in more bunch rot. Spayd et al. (1994) concluded that increased canopy size and delayed harvest caused by increasing $\mathrm{N}$ fertilisation probably increased the incidence of $B$. cinerea infection, but their conclusion was based on non-quantitative observations. The phenolic concentrations of the Riesling grapes investigated decreased quadratically with increased $\mathrm{N}$ fertilisation.

Increased yield parameters can have multiple effects on bunch rot expression. Increased fruit set results in more berries in the bunch (Spayd et al. 1993) and may lead to tighter bunches, increasing the risk of bunch rot in some varieties. However, the increased yield reported in some $\mathrm{N}$ experiments also resulted in a decrease in soluble sugars (Spayd et al. 1993; Christensen et al. 1994; Spayd et al. 1994) as source to sink ratios differed between vines with and without the $\mathrm{N}$ additions. This delay in sugar accumulation should decrease the risk of individual berries expressing disease, since berry soluble solids is highly correlated to berry susceptibility to infection (Mundy \& Beresford 2007). Berries that develop later in the season under cool climate conditions experience a lower average temperature in the field and hence require much longer wetness periods for successful $B$. cinerea infection. In climates such as Marlborough duration of wetness periods is not a seasonal factor but temperature during wetness periods is. Therefore the expression of disease in the field may be due to a combination of indirect effects that result from a single addition of $\mathrm{N}$ to the vine.

Keller et al. (2001) found that $\mathrm{N}$ application could increase bunch stem necrosis, $B$. cinerea bunch rot and yield. The severity of $B$. cinerea infection was correlated with the number of berries in the bunch (due to improved fruit set) and with bunch weight. They concluded that more compact bunches, from improved fruit set due to $\mathrm{N}$ addition, resulted in bunches that were more susceptible to $B$. cinerea infection. These results are consistent with Christensen et al. (1994) who reported a significant increase in yields in response to $\mathrm{N}$ additions. They also reported more rots in sensitive vines with the highest experimental $\mathrm{N}$ rate and/or the véraison application timing. They defined rot as berries with four or more adjoining berries showing decay.

More targeted experiments investigating the effects of $\mathrm{N}$ fertiliser, green pruning and fungicide use on botrytis bunch rot (R'Houma et al. 1998) reported that vines 
were predisposed to increased disease severity after high $\mathrm{N}$ fertilisation. However, when green pruning practices such as leaf plucking were added to the $\mathrm{N}$ fertilisation treatments, botrytis bunch rot severity was reduced to less than $5 \%$ of berries regardless of $\mathrm{N}$ treatment.

\section{CONCLUSIONS}

Nitrogen is an important macro-nutrient for the growth and defence of grapevines because it has a direct effect on fruit set and vegetative growth. High $\mathrm{N}$ nutrition can make the micro-environment more suitable to bunch rots but low $\mathrm{N}$ may adversely affect the quality of the juice since wines with richer flavour and aroma are produced from berries with optimum N levels (Goldspink \& Frayne 1996; Dawson 2001). However, low berry $\mathrm{N}$ does not make the fruit less susceptible to infection since there are a number of $B$. cinerea genes that allow growth at low cell nutrient contents.

The aim of any $\mathrm{N}$ fertilisation method should be to increase juice $\mathrm{N}$ content to optimum levels while preventing excessive vegetative growth. This can be achieved under New Zealand conditions with vineyard mulches (Agnew et al. 2002), and may also be achieved by adding small amounts of $\mathrm{N}$ soon after véraison in the form of calcium nitrate, a compound that prevents soil acidification, which occurs with some $\mathrm{N}$ fertilisers. It is clear that small adjustments in $\mathrm{N}$ have the potential to have large and varied effects on the vines, so any changes contemplated should be considered within the context of the overall vineyard management programme. The management of vineyard $\mathrm{N}$, and hence juice $\mathrm{N}$, has the potential to improve the quality and marketability of New Zealand wines. Developing environmentally sustainable production systems that provide juice with the optimum $\mathrm{N}$ content is a goal consistent with the objectives of the New Zealand Wine industry and is likely to be an area of future investigation.

Further research is needed to improve current understanding of the interactions between $\mathrm{N}$ manipulations in the vineyard, wine quality and botrytis bunch rot susceptibility. This should involve pathologists and physiologists working together to optimise fruit $\mathrm{N}$ composition without indirectly causing increases in disease.

\section{ACKNOWLEDGEMENTS}

Funding for this project was provided by New Zealand Winegrowers and the Ministry of Agriculture and Forestry Sustainable Farming Fund.

\section{REFERENCES}

Agnew R, Mundy D, Balasubramaniam R 2004. Effects of spraying strategies based on monitored disease risk on grape diseases control and fungicide usage in Marlborough. New Zealand Plant Protection 57: 30-36.

Agnew R, Mundy D, Spiers M 2002. Mulch for sustainable production. HortResearch, Blenheim. 48 pp.

Bell SJ, Henschke PA 2005. Implications of nitrogen nutrition for grapes, fermentation and wine. Australian Journal of Grape and Wine Research 11 (3): 242-295.

Christensen LP, Bianchi ML, Peacock WL, Hirschfelt DJ 1994. Effect of nitrogen fertiliser timing and rate on inorganic nitrogen status, fruit composition, and yield of grapevines. American Journal of Enology and Viticulture 45 (4): 377-387.

Commenil P, Brunet L, Audran J-C 1997. The development of the grape berry cuticle in relation to susceptibility to bunch rot disease. Journal of Experimental Botany 48 (313): 1599-1607.

Dawson P 2001. Growing great reds, Australian reds - how do they do it? Presentation to Romeo Bragato Conference, Napier Municipal Theatre, Hawke's Bay.

Elmer PAG, Michailides TJ 2004. Epidemiology of Botrytis cinerea in orchard and vine crops. In: Elad Y, Williamson B, Tudzynski P, Delen N ed. Botrytis: Biology, Pathology and Control. Kluwer Academic Publishers, Dordrecht. Pp. 243-272.

Goldspink B-H, Frayne B 1996. The effect of nutrients on vine performance, juice parameters and fermentation characteristics. In: Goldspink B-H, Howes KM ed. Fertilisers for wine grapes - an information package to promote efficient fertiliser practices. Agriculture Western Australia, Mildura. 12 pp. 
Gubler WD, Marois JJ, Bledsoe AM, Bettiga LJ 1987. Control of Botrytis bunch rot of grape with canopy management. Plant Disease 71 (7): 599-601.

Hill G, Stellwaag-Kittler F, Huth G, Schlosser E 1981. Resistance of grapes in different developmental stages to Botrytis cinerea. Phytopathology 102: 328-338.

Holz G, Coertze S, Williamson B 2004. The ecology of Botrytis on plant surfaces. In: Elad Y, Williamson B, Tudzynski P, Delen N ed. Botrytis: Biology, Pathology and Control. Kluwer Academic Publishers, Dordrecht.

Huber DM, Thompson IA 2007. Nitrogen and plant disease. In: Datnoff LE, Elmer WH, Huber DM ed. Mineral nutrition and plant disease. The American Phytopathological Society, St. Paul, Minnesota, USA. Pp. 31-44.

Keller M, Arnink KJ, Hrazdina G 1998. Interaction of nitrogen availability during bloom and light intensity during veraison. I. Effects on grapevine growth, fruit development, and ripening. American Journal of Enology and Viticulture 49 (3): 333-340.

Keller M, Hrazdina G 1998. Interaction of nitrogen availability during bloom and light intensity during veraison. II. Effects on anthocyanin and phenolic development during grape ripening. American Journal of Enology and Viticulture 49 (3): 341-349.

Keller M, Kummer M, Vasconcelos MC 2001. Reproductive growth of grapevines in response to nitrogen supply and rootstock. Australian Journal of Grape and Wine Research 7: 12-18.

Keller M, Steel CC, Creasy GL 2000. Stilbene accumulation in grapevine tissues: developmental and environmental effects. Acta Horticulturae 514: 275-286.

Mundy DC, Agnew RH 2002. Effects of mulching with vineyard and winery waste on soil fungi and Botrytis bunch rot in Marlborough vineyards. New Zealand Plant Protection 55: 135-138.

Mundy DC, Beresford RM 2007. Susceptibility of grapes to Botrytis cinerea in relation to berry nitrogen and sugar concentration. New Zealand Plant Protection 60: 123-127.

R'Houma A, Cherif M, Boubaker A 1998. Effect of nitrogen fertilization, green pruning and fungicide treatments on Botrytis bunch rot of grapes. Journal of Plant Pathology 80 (2): 115-124.

Rogiers SY, Greer L, Weckert M, Steel C, Schmidtke L, Holzapfel BP 2003. Agricultural spray adjuvants: effects on grape berry wax, berry microflora and subsequent botrytis infection. The Australian \& New Zealand Grapegrower \& Winemaker. Pp. 19-21.

Rogiers SY, Whitelaw-Weckert M, Radovanonic-Tesic M, Greer LA, White RG, Steel CC 2005. Effects of spray adjuvants on grape (Vitis vinifera) berry microflora, epicuticular wax and susceptibility to infection by Botrytis cinerea. Australasian Plant Pathology 34 (2): 221-228.

Smart R, Robinson M 1991. Sunlight into Wine: A Handbook for Winegrape Canopy Management. Winetitles, Adelaide. 88 pp.

Snoeijers SS, Perez-Garcia A, Joosten MHAJ, De Wit PJGM 2000. The effect of nitrogen on disease development and gene expression in bacterial and fungal plant pathogens. European Journal of Plant Pathology 106: 493-506.

Spayd SE, Nagel CW, Edwards CG 1995. Yeast growth in Riesling juice as affected by vineyard nitrogen fertilisation. American Journal for Enology and Viticulture 46 (1): 49-55.

Spayd SE, Wample RL, Stevens RG, Evans RG, Kawakami AK 1993. Nitrogen fertilisation of white Riesling in Washington: effects on petiole nutrient concentration, yield, yield components, and vegetative growth. American Journal for Enology and Viticulture 44 (4): 378-386.

Spayd SE, Wample RL, Stevens RG, Evans RG, Seymour BJ, Nagel CW 1994. Nitrogen fertilisation of white Riesling grapes in Washington. Must and wine composition. American Journal for Enology and Viticulture 45 (1): 34-42.

van Kan JAL 2006. Licensed to kill: the lifestyle of a necrotropic plant pathogen. Trends in Plant Science 11 (5): 247-253. 